\title{
Initial Effects of Brush Cutting and Shoot Removal on Willow Browse Quality
}

\author{
Roy V. Rea ${ }^{1}$ and Michael P. Gillingham ${ }^{2}$
}

Authors are ${ }^{1}$ Senior Laboratory Instructor and ${ }^{2}$ Associate Professor, Ecosystem Science and Management Program and Natural Resources and Environmental Studies Institute, University of Northern British Columbia, 3333 University Way, Prince George, British Columbia, Canada, V2N $4 Z 9$.

\begin{abstract}
We examined the initial effects of brush cutting (removal of all aboveground biomass), as well as clipping (removal of current annual shoots) and ungulate browsing (collectively referred to as shoot removal) on the morphology and nutrient quality of Scouler's willow (Salix scouleriana J. Barratt ex Hook.) for ungulates on sites 2 and 4 years after brush cutting. We specifically assessed changes in the biomass, tannin content, digestible energy, and digestible protein of shoots from brush-cut willows relative to shoots of uncut willows to determine how browse plants respond to this form of vegetation management. In winter, the resprouted current annual shoots of willows that had been brush cut were larger in mass and lower in digestible protein than shoots of uncut willows for at least 4 years after brush cutting. Shoots of brush-cut willows were also lower in tannin and digestible energy than the shoots of uncut plants for two winters after brush cutting. In the second winter after brush cutting, shoot biomass decreased and tannin content increased with increasing shoot removal during the previous winter. In the fourth winter after brush cutting, shoot mass increased and digestible energy decreased in shoots with greater shoot removal. Nutrient quality was otherwise unaffected by the amount of shoot removal during the previous winter. Because of the occasional importance of site effects in this study, we recommend that long-term studies maximize the number of sampled sites. Because brush cutting alters the quality of regenerating browse and can affect how ungulates utilize such browse for several years after brush cutting, we further recommend that forest vegetation managers consider potential impacts of brush cutting on ungulate winter range.
\end{abstract}

\section{Resumen}

Examinamos los efectos iniciales del corte de arbustos (remoción de toda la biomasa aérea), corte (remoción del crecimiento del año en curso), y el ramoneo por ungulados (referidos colectivamente como remoción de ramas) sobre la morfología y calidad de nutrientes del Scouler's willow (Salix scouleriana J. Barratt ex Hook.) para los ungulados en sitios con 2 y 4 años posteriores al corte de arbustos. Específicamente evaluamos los cambios de la biomasa, contenido de taninos, energía y proteína digestibles de las ramas de "Scouler's willow" con corte de arbustos en relación a ramas de "Scouler's willow" sin corte de arbustos (sin corte) para determinar como las plantas responden a esta forma de manejo de la vegetación. En invierno, las ramas rebrotadas en el año en curso de plantas de "Scouler's willow" que habían recibido corte de arbusto fueron superiores en biomasa y más bajas en proteína digestible que las ramas sin corte, al menos cuatro años después del corte de arbustos. Durante los dos inviernos posteriores al corte de arbustos, las ramas de "Scouler's willow" con corte de arbusto también presentaron contenidos más bajos de taninos y energía digestible que las ramas de plantas sin corte. En el segundo invierno después del corte, la biomasa de las ramas disminuyó y el contenido de taninos incrementó con el aumento de la remoción de ramas durante el invierno previo. En el cuarto invierno después del corte de arbustos, con una mayor remoción de ramas, la biomasa de las ramas aumentó y la energía digestible disminuyó. La calidad de nutrientes no fue afectada por la cantidad de remoción de ramas en el invierno previo. Debido a la importancia ocasional de los efectos del sitio en este estudio, recomendamos que estudios de largo plazo maximicen el número de sitio de muestro. Dado que el corte de arbustos altera la calidad del forraje ramoneadle en regeneración y puede afectar como los ungulados utilizan tal forraje por varios años después del corte de los arbustos, nosotros además recomendamos que los manejadores de la vegetación del bosque consideren los impactos potenciales del corte de arbustos sobre el pastizal invernal de los ungulados.

Key Words: forage, moose, plant response, Salix scouleriana, silviculture, ungulate, vegetation management

\section{INTRODUCTION}

Management of forest vegetation influences wildlife food and cover. In particular, herbicide and mechanical brush cutting

Research was funded by Forest Renewal British Columbia Grant FR-96/97-093, the Prince George Regional office of the British Columbia Forest Service, and the University of Northern British Columbia. In-kind contributions from the Vanderhoof District of the British Columbia Forest Service are acknowledged.

Correspondence: Roy V. Rea, Ecosystem Science and Management Program, University of Northern British Columbia, Prince George, British Columbia, Canada, V2N 4Z9. Email: reav@unbc.ca

Manuscript received 6 December 2005; manuscript accepted 19 August 2007. operations that reduce competition of woody deciduous plants (e.g., willows Salix spp.) with planted conifers also reduce browse for ungulates (Hjeljord and Grønvold 1988; Posner and Jordan 2002). How herbicides and some mechanical treatments such as roller chopping affect deciduous browse availability and quality has been studied (Hjeljord 1994; Raymond et al. 1996; Schindler et al. 2004).

Brush cutting differs from roller chopping and other forms of mechanical control in that plants are sawn cleanly at the point of top removal with brush saws rather than shattered or crushed (Bell et al. 1997); the angle of cut, stump height, and surface exposure of the stump at the point of top removal significantly influences how plants respond to damage (Har- 
rington 1984; Bell et al. 1997). Brush cutting is known to alter plant quality and availability in the short term (1-2 years; Bryant et al. 1985; Rea and Gillingham 2001). However, the influence that brush cutting has on somewhat longer-term initial effects of brush cutting and subsequent removal of shoots by browsing and clipping on the chemistry and morphology of browse shoots is less understood.

Brush cutting is replacing herbicide applications in many Canadian jurisdictions (Lautenschlager 1993; Rea 1999; Posner and Jordan 2002) and can occur wherever forests are being managed, including ungulate winter and cattle summer ranges. Because this form of vegetation management is expanding, and our understanding of how such treatments specifically influence browse quality and availability is limited, we examined the initial effects of brush cutting and subsequent shoot removal on plant quality. We selected an important browse (Scouler's willow; Salix scouleriana Barratt ex Hook.) for ungulates (Alldredge et al. 2002) to examine the effects of brush cutting and shoot removal from clipping and browsing on shoot morphology and nutrient (chemical) quality in the second and fourth winter following brush cutting.

\section{METHODS}

\section{The Study Area}

We studied six sites that were clear-cut logged (ranging from 15 to $40 \mathrm{ha}$ in size) and then planted in lodgepole pine (Pinus contorta Dougl. ex Loud. var. latifolia Engelm.) near Vanderhoof, British Columbia, Canada (lat $54^{\circ} 05^{\prime} \mathrm{N}$, long $123^{\circ} 55^{\prime} \mathrm{W}$ ). All sites are characterized by open stands of lodgepole pine with poorly developed shrub and herb layers, and a welldeveloped moss layer dominated by lichens; soils on all sites are clay and/or sandy loam (Rea 1999).

To determine the effects of brush cutting (i.e., the mechanical removal of all aboveground biomass) on willows, we selected six sites where brush cutting had been conducted either 2 or 4 years previously. Three of the sites (i.e., Layton, Buck and Sackner) were clear-cut logged 12 to 15 years prior to our study (early 1980s); these three sites were then brush cut during the 1993 growing season (June to September) and we sampled them 4 years after brush cutting (winter of 1996-1997). The other three sites (i.e., Sawmill, Huckleberry, and Waterlily) were clear-cut logged 9 to 11 years prior to the beginning of the study (mid 1980s) and were brush cut during the 1995 growing season (sampled 2 years after brush cutting; winter of 19961997).

During brush cutting operations in 1993 and 1995, all aboveground biomass, except approximately $10 \mathrm{~cm}$ of stump tissue, was removed from willows and all other deciduous shrubs and trees on each site. The tops of the plants were left scattered on the site to decompose. Wildlife strips (sensu Santillo 1994; areas established for wildlife food and cover after clear-cut logging but prior to brush cutting treatments) were not brush cut on each of the six sites and contained willows about 4 to $5 \mathrm{~m}$ tall at the beginning of this study; willows that had been brush cut had regrown to approximately 1 to $2 \mathrm{~m}$ in height at the time of the study. All sites (except Waterlily) had a long history of browse utilization by moose (Alces alces L.) and deer (Odocoileus spp.). Additionally, free- range cattle (Bos taurus L.) utilized Buck and Sackner sites in summer.

\section{Experimental Design}

During the winter of 1995-1996, we randomly selected six Scouler's willow plants from brush-cut areas and six willows from the wildlife strips (controls) on each of the three plantation sites that had been brush cut in 1993 (i.e., Layton, Buck, and Sackner) and each of the three sites brush cut in 1995 (i.e., Sawmill, Huckleberry, and Waterlily). We removed current annual shoots accessible above the snowpack from the sampled plants by clipping at specific intensities in order to simulate the removal of current shoots by moose (Danell et al. 1997). We collected no shoots, every third shoot, two of every three shoots, or all shoots for $33 \%, 66 \%$, and $100 \%$ shoot removals, respectively.

Because of unanticipated browsing by moose (increase in intended treatment of shoots) and snow burial of stems at the time of our clipping (decrease in intended treatment of shoots), we were forced to reassess the actual shoot removal on each plant. In the spring of 1996, therefore, we determined the percentage of shoots removed by clipping and subsequent overwinter ungulate browsing by counting all overwintering shoots and classifying them as browsed/clipped or undamaged and then dividing the number of browsed/clipped shoots by the total number of shoots on the plant. We quantified the range of clipping in combination with natural browsing $(0 \%$ to $98 \%$ shoots removed) and treated shoot removal (clipping plus browsing) as a covariate in our ANCOVA analyses described below.

In December of 1996, we visited each of our six sites and harvested shoot samples (between 20 and 300 shoots from brush cut and between 200 and 800 shoots from uncut willows based on the percentage removals in our original treatments) in subzero weather while plants were dormant to inhibit postsampling metabolic activities within the shoot tissues. Sampled shoots were clipped at the current annual growth scar. Shoots were collected early in winter so as to avoid damage from winter browsing, but in some cases shoots showed signs of summer browsing by cattle or deer. Shoots were used to assess morphological and chemical attributes of our study plants as described below.

Collections from each willow were placed in separate plastic freezer bags in the field for 1) tannin analysis, and 2) all other analyses. Following collections, bags were sealed and then stored at $-20^{\circ} \mathrm{C}$ until analyzed. All shoots were weighed to determine mass. If more than 30 shoots were collected from a willow, we randomly subsampled 30 shoots for morphometric measurements. Following morphometric measurements, all shoot material for each plant was combined, sectioned to approximately 10 $\mathrm{cm}$ lengths and dried to a constant mass $( \pm 0.1 \mathrm{~g})$ at $39^{\circ} \mathrm{C}$ in a forced-draft drying oven (Despatch LAD series 2-24-3; Despatch Industries, Minneapolis, MN). We then milled the dried material with a Thomas-Wiley mill (Swedesboro, NJ) using a $0.5-\mathrm{mm}$ sieve screen, and hand mixed the samples to homogenize them. Gross energy was determined with a bomb calorimeter (Parr model 1341; Parr Instrument Company, Moline, IL) using 0.75 to $1.0 \mathrm{~g}$ of material and procedures outlined by the manufacturer. Gross energy values were corrected 
to dry mass by desiccating with anhydrous $\mathrm{CaSO}_{4}$ (W. A. Hammond Drierite Co., Xenia, OH) for 24 hours.

We determined elemental nitrogen using an elemental $\mathrm{CHN}$ analyser (Na Series 2; Carlo Erba Instruments, Milano, Italy) following procedures outlined by the manufacturer and Pella and Colombo (1973). The elemental analyser was calibrated using atropine $(4.84 \% \mathrm{~N})$ and the National Institute of Standards and Technology standard number 1573a (3.03\% $\mathrm{N})$. Because elemental nitrogen approximates the nitrogen content of a sample with the same accuracy and precision as total Kjeldahl nitrogen (TKN; Hellinga et al. 1998), we substituted elemental nitrogen for TKN in equations outlined in Hanley et al. (1992) for estimating digestible protein. Digestible dry matter was used to compute in vitro digestible energy (gross energy $\times$ digestible dry matter). We computed digestible dry matter using equations developed for deer (Odocoileus spp.) and other cervids that secrete salivary tannin-binding proteins, as described in Hanley et al. (1992).

We used a fiber-refluxing/distillation apparatus (Labconco model 30006; Labconco Corporation, Kansas City, MO) and procedures outlined in Goering and Van Soest (1970) to estimate the fiber fractions in our samples for use in determining digestible dry matter. We omitted sodium sulphite from the Neutral Detergent Fiber (NDF) procedure as recommended by Hanley et al. (1992) for the determination of NDF from browse stems. We also omitted the optional wash with hexane from the Acid Detergent Fiber (ADF) procedure (Goering and Van Soest 1970). We did not use asbestos in the determination of acid detergent lignin (Goering and Van Soest 1970). We standardized NDF and ADF protocols by using standard forage mix samples from Norwest Labs (Lethbridge, Alberta).

We followed the recommendation of Hanley et al. (1992) and did not apply the tannin correction factor in calculations for either digestible protein or digestible dry matter because dormant twigs contain relatively small amounts of tannin (Palo 1984). Although crude tannin content was not quantified for use in digestibility determinations, we did determine the relative differences in tannin content between samples from the different brush cutting treatments in order to help understand changes to one of the chemical characteristics known to influence winter browse selection by moose. We assessed tannin content using a radial diffusion protein precipitation assay that we modified from Hagerman (1987; Rea 1999).

\section{Statistical Analyses}

To test the effect of brush cutting on the morphology and chemistry of willow shoots, we used a nested analysis of covariance (ANCOVA; Zar 1999) with the percentage of shoots that were clipped or browsed during the previous year used as a covariate. Treated willows (brush cut vs. uncut) were considered to be nested within sites. In the nested ANCOVA model, we treated site as a random effect and treatment (brush cut or uncut) as a fixed effect. We used PROC GLM for the mixed model in SAS (SAS 2005) specifying the appropriate test terms for the random and fixed effects. Least-square means (LSMEANS statement) were calculated for all model effects. We report back-transformed, adjusted means (and standard errors), which represent the marginal means for each effect adjusted for all other factors in the ANCOVA model (e.g.,
Table 1. Results ( $P$ values) of comparisons between brush cut and uncut willows for morphological and chemical attributes in the second (1995 brush-cut sites) and fourth (1993 brush-cut sites) years after brush cutting treatments. Data were analyzed with a nested ANCOVA (see text). The shoot removal column indicates the significance of the effect of the percentage of shoots that were clipped or browsed during the previous winter. Where the effect of the shoot removal covariate was significant, $a+$ or - sign indicates the slope of the covariate (see text). DM indicates dry matter.

\begin{tabular}{|c|c|c|c|c|}
\hline $\begin{array}{l}\text { Years since } \\
\text { brush cutting }\end{array}$ & Shoot attribute & $\begin{array}{l}\text { Treatment (brush } \\
\text { cut/uncut) }\end{array}$ & $\begin{array}{l}\text { Shoot } \\
\text { removal }\end{array}$ & Site \\
\hline \multirow[t]{4}{*}{2} & Biomass (g) & $<0.001$ & $0.001(-)$ & 0.898 \\
\hline & Tannin content $^{1}$ & 0.013 & $0.022(+)$ & 0.542 \\
\hline & Digestible energy $\left(\mathrm{kcal} \cdot \mathrm{g}^{-1}\right)$ & $<0.001$ & 0.203 & 0.456 \\
\hline & Digestible protein (\% DM) & 0.011 & 0.389 & 0.587 \\
\hline \multirow[t]{4}{*}{4} & Biomass (g) & 0.007 & $0.014(+)$ & 0.080 \\
\hline & Tannin content ${ }^{1}$ & 0.545 & 0.304 & 0.027 \\
\hline & Digestible energy $\left(\mathrm{kcal} \cdot \mathrm{g}^{-1}\right)$ & 0.095 & $0.046(-)$ & 0.164 \\
\hline & Digestible protein (\% DM) & 0.035 & 0.744 & 0.483 \\
\hline
\end{tabular}

${ }^{1}$ Tannin content is based on tannin reactivity to bovine serum albumin and is quantified using a radial diffusion assay modified from Hagerman (1987; see Methods).

covariate effects set to their mean value). Significant differences in adjusted site effects were tested with Tukey's range test. Homogeneity of variances was tested using a Levene's test (Milliken and Johnson 1984). A Kolmogorov-Smirnov test was used to test assumptions of normality (Zar 1999). Where appropriate, square root, inverse, inverse square root, or log transformations (Tabachnick and Fidell 1996) were applied to normalize data and/or homogenize the variance of the shoot attribute being tested between treatments. Where an effect of the covariate was significant, we further explored the significance with linear regression analysis and report the direction of the slope of the response variable regressed on the covariate. Because the sites were initially treated in different years (i.e., 1993 and 1995), times of post-brush cutting are 2 years for Huckleberry, Waterlily, and Sawmill (1995) sites, and 4 years for Buck, Layton, and Sackner (1993) sites. The $\alpha$ for all analyses was 0.05 .

\section{RESULTS}

\section{Shoot Morphology}

Willows responded to brush cutting by producing shoots that were significantly heavier than the shoots of uncut willows (as much as four to five times heavier on Sawmill and Huckleberry sites) for 2 (Table 1; Figure 1) and 4 (Table 1; Figure 2) years after brush cutting. Biomass of shoots, however, was also affected by shoot removal during the previous winter from clipping and browsing, but the effect of shoot removal was different 2 and 4 years after brush cutting (Table 1). In the second winter after brush cutting, shoot mass decreased with increasing shoot removal (Table 1; negative slope of shoot removal in year 2). In contrast, sites that were measured 4 years after brush cutting had shoots whose biomass generally increased with increasing shoot removal during the winter before measurement (Table 1 and Figure 3A; positive slope of covariate in year 4). For the 4-year, post-brush cutting replicates, site was not significant (Table 1), but the Layton 

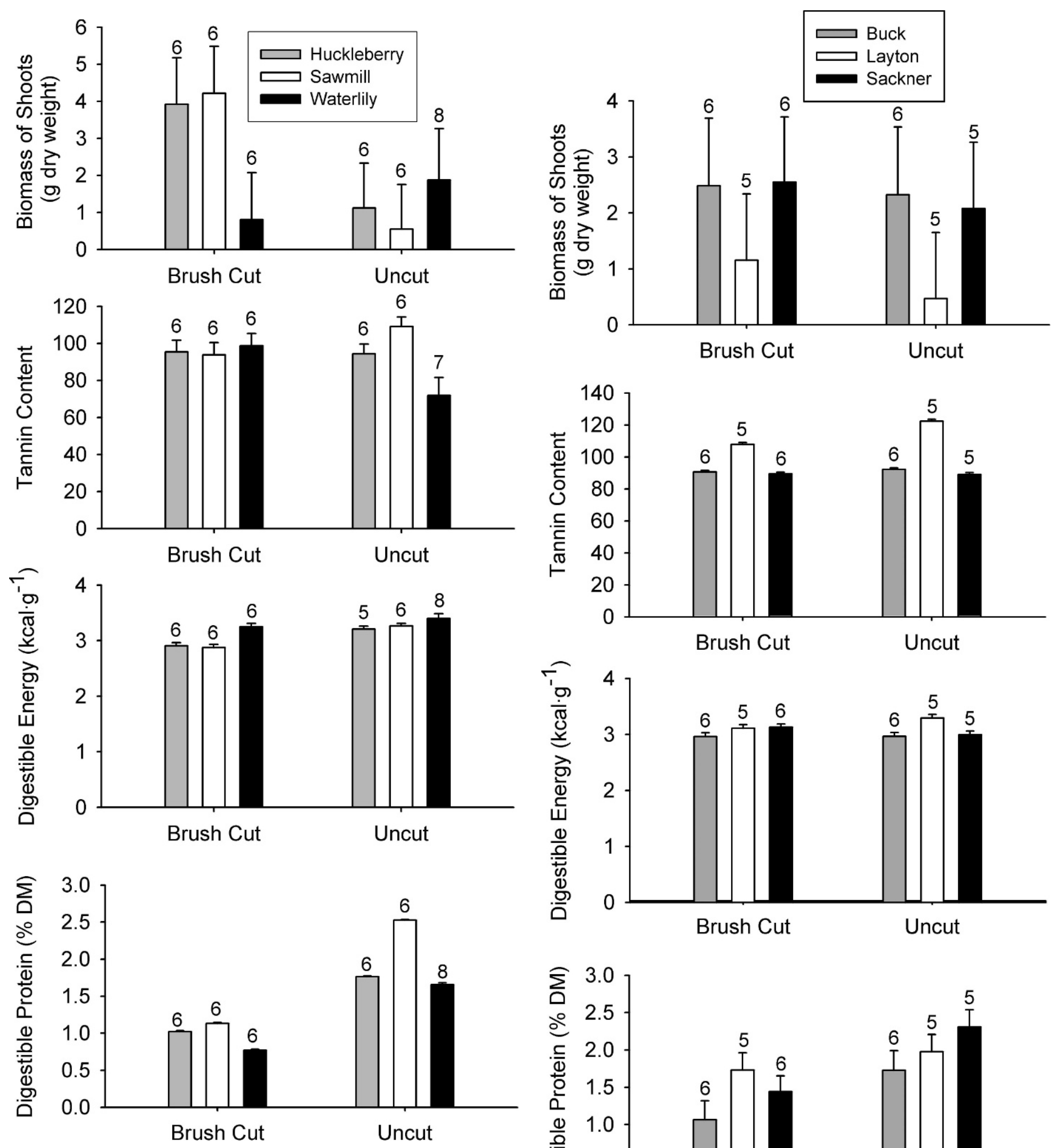

Figure 1. Comparisons of mean (and SE) morphological and chemical attributes of shoots from brush-cut and uncut willows collected in the second year after brush cutting (1995 brush-cut sites). DM indicates dry matter. Sample sizes are shown above each error bar. Means (and SE) are the backtransformed means adjusted for all other factors in the ANCOVA model (SAS: LSMEANS) including the covariate of the amount of current annual shoots removed by clipping and browsing.

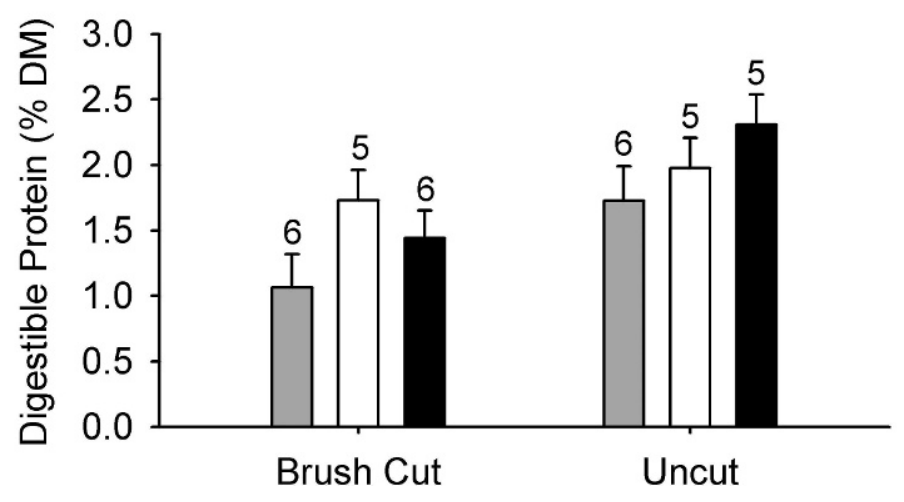

Figure 2. Comparisons of mean (and SE) morphologicaland chemicalattributes of shoots from brush-cutand uncut willows collected in the fourth year after brush cutting (1993 brush-cut sites). DM indicates dry matter. Sample sizes are shown above each error bar. Means (and SE) are the back-transformed means adjusted for all otherfactors in the ANCOVA model (SAS: LSMEANS) including the covariate of the amount of current annual shoots removed by clipping and browsing. 


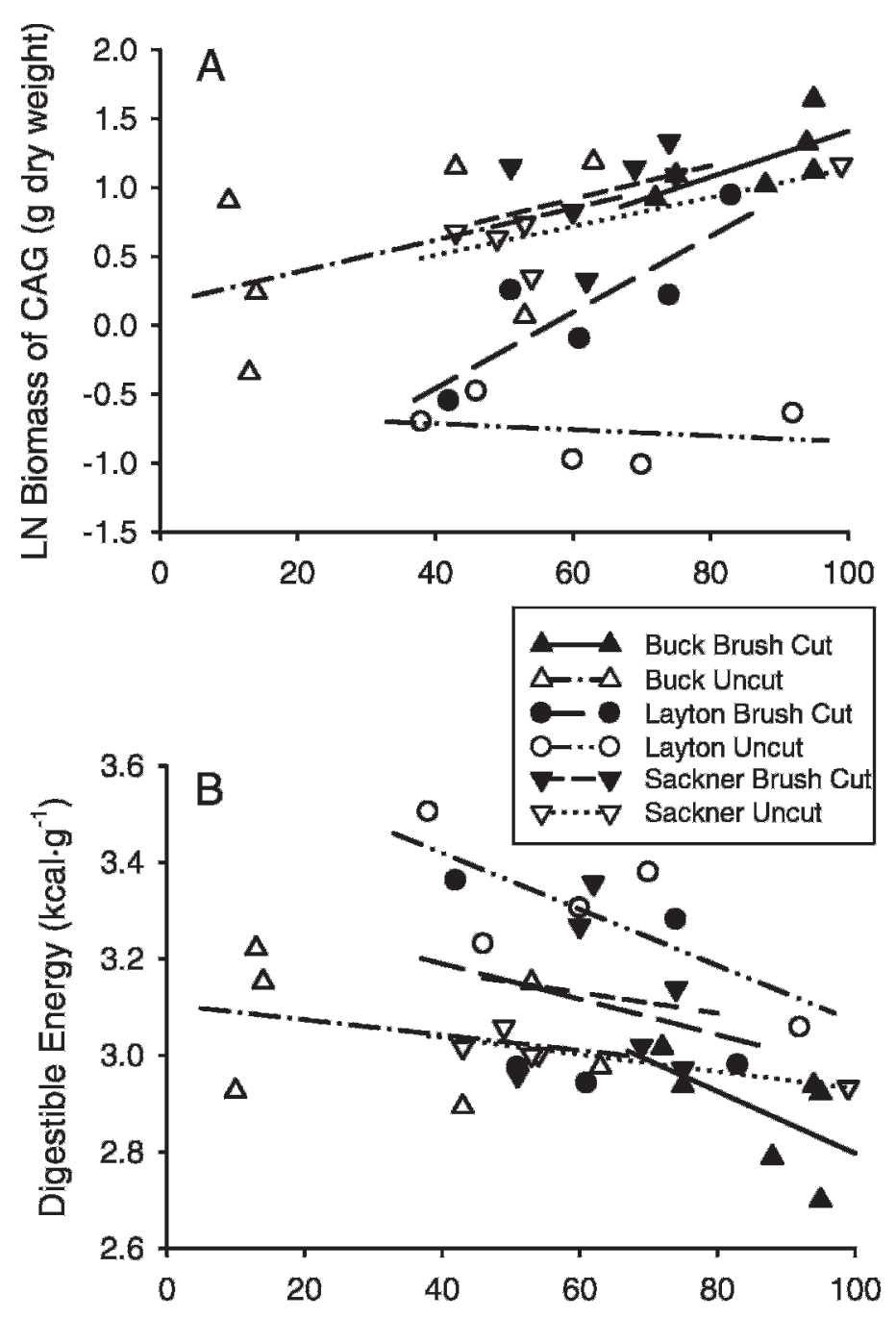

Percent CAG Removed During Previous Winter

Figure 3. Scatter plots illustrating two examples of the effect of the covariate on the natural logarithm of biomass $(\mathbf{A})$ and on digestible energy (B) in the fourth year after brush cutting for three sites brush cut in 1993. Each regression line represents the influence of the covariate (percent removal) on the dependent variable. The significance of the covariates are presented in Table 1.

uncut samples showed a different response than the other site treatments to increasing shoot removal (Figure 3A).

\section{Shoot Chemistry}

The response of tannin content was different between the 2year and 4-year postcutting treatments. Tannin content was lower in the brush-cut shoots in the second year after brush cutting (Table 1; Figure 1), but not in sites measured 4 years after cutting (Table 1; Figure 2). On sites measured 2 years after brush cutting, shoot tannin content increased with increasing shoot removal (Table 1; positive slope of shoot removal in year 2). Tannin content was unaffected by shoot removal at the sites measured 4 years after brush cutting. There was, however, a significant effect of site on tannin content of shoots (Table 1) at the 4-year postcutting sites: the shoots of both brush-cut and uncut willows growing on our Layton site had significantly higher tannin content than sampled willows growing on Sackner and Buck sites.

The response of digestible energy content of shoots differed between sites measured 2 and 4 years after brush cutting. Brush cutting reduced the digestible energy content of willow shoots 2 years after cutting (Table 1; Figure 1), but there was no response in digestible energy content of shoots to brush cutting on sites measured 4 years after cutting (Table 1; Figure 2). Conversely, there was no response in digestible energy content to shoot removal 2 years after brush cutting, but on the 4-year sites, digestible energy decreased with increasing intensity of shoot removal (Table 1 and Figure 3B; negative slope of shoot removal in year 4). Site by itself did not explain significant variation in digestible energy (Table 1 ).

Digestible protein was lower in the shoots of brush-cut plants on both 2- and 4-year, postcutting sites (Table 1; Figures 1 and 2 ). Digestible protein was unaffected by the intensity of the previous year's shoot removal, or by site alone (Table 1 ).

\section{DISCUSSION}

\section{Plant Response}

We observed that the effects of brush cutting on Scouler's willow included increases in shoot mass (but also shoot length and basal diameter; Rea 1999) and decreases in digestible protein for at least 4 years post-brush cutting, and reductions in digestible energy and tannin content in the short term. Others have reported related effects on desert shrubs following roller chopping (Schindler et al. 2004), but the longer-term effects of brush management on woody browse availability and quality are largely unknown (Allegretti et al. 1997).

Plants generally respond to increased clipping intensities by producing large shoots (Bergström and Danell 1987), but decreases in shoot sizes with increased clipping intensities during the previous year might also occur when plants are severely stressed (Danell and Bergström 1989). This type of response could help to explain why Scouler's willows in our study produced larger compensatory shoots with increased shoot-removal intensity 4 years after brush cutting, but not when intense shoot removal was measured 2 years after brush cutting (clipped during the previous winter). Vigorous vegetative regeneration and the production of large compensatory shoots following mechanical damage (i.e., cutting, browsing) is a growth strategy employed by several species of willows (Sennerby-Forsse and Zsuffa 1995). This type of growth response to damage is particularly adaptive for plants such as Scouler's willow growing in young boreal forests where plant competition for canopy occupancy is intense (Aarssen and Irwin 1991) and where the highest herbivore pressures are exerted closest to the ground (Danell et al. 1987).

Although ungulates, such as moose, are known to break down and browse the smaller top shoots of taller $(6$ to $9 \mathrm{~m})$ birches (Danell and Bergström 1985), large shoots and sprouts produced in the years after intense tissue removal are particularly attractive to large ungulates (Danell et al. 1985; Singer et al. 1994; Bergström and Guillet 2002; Hessl and Graumlich 2002). Selecting more massive shoots enables large ungulates to increase bite size and intake rates per cropping effort (Gross et al. 1993; 
Shipley et al. 1994), which can facilitate maximizing energy intake while minimizing the amount of time spent foraging.

Except for digestible protein, changes in the chemical attributes of willow shoots following brush cutting appear to be less persistent than corresponding increases in shoot mass. Shoots from brush-cut plants were lower in tannin content and digestible energy for 2 , but not 4 , winters after brush cutting. Additionally, the lignin content of these shoots was reduced for 2, but not 4, years after brush cutting (Rea 1999). Our chemical analyses indicate that reductions in digestibility were due to increases in structural materials such as cellulose and hemicellulose (as determined by detergent analysis) apparently synthesized to support the growth of large compensatory shoots.

The tannin content of willow shoots produced in the year after shoot removal increased with an increase in the previous year's intensity of shoot removal when analyzed in the second winter after brush cutting. Although plants stressed by repeated hare browsing following cutting have been shown to produce shoots that are higher in phenolic compounds such as tannins (Bryant et al. 1985), reductions in the tannin and lignin content of browse shoots following various forms of plant damage are also reported (Nellemann 1990, crushing; Singer et al. 1994, clipping; Schindler et al. 2004, roller chopping).

Shoots lower in phenolics, such as tannins and lignins, are selected by browsers, regardless of digestibility (Bryant et al. 1983; Risenhoover 1987; Singer et al. 1994). These chemicals interfere with rumen microbial activity (Blair et al. 1980), reducing shoot nutrient quality (Spalinger et al. 1986; Shipley and Spalinger 1992), and are specifically avoided by ungulates (Risenhoover 1987; Nellemann 1990). Cervids appear to avoid tannin-containing browses even though such animals produce salivary-tannin-binding proteins to help neutralize the effects of dietary tannins (Hagerman and Robbins 1993; Juntheikki 1996). Such avoidance might be related to the inability of animals to completely bind all tannins in deciduous browse (including some willows; Juntheikki 1996).

Although dormant browse stems contain relatively little tannin when compared to other forage items (Hagerman and Robbins 1993), these small amounts of tannin are sufficient to bind all of the tannin-binding protein from moose saliva (Juntheikki 1996). The production of shoots with even slight reductions in tannin content, such as those produced in the second year after brush cutting, therefore, might well increase browse quality - at least in the short term. The smaller shoots of uncut plants in this study might be due to the growthinhibiting effects of tannins, rather than declines in tannin content being due to the allocation of resources towards growth and away from chemical defence; resource availability is known to drive the production and accumulation of tannins (Coley et al. 1985). Reductions in tannin content are likely due to the allocation of plant resources into shoot elongation or physical defences (Schindler et al. 2004) rather than the production of chemical defences.

\section{Site Effects}

An important result of this study is the lack of consistency among sites in the measured plant response (Table 1) both in terms of shoot biomass and chemistry. For example, variations in resource availability between sites might help to explain the differences in tannin content that we detected between willows growing on the Layton vs. Sackner and Buck sites. Although sites were chosen to maximize similarity among sites, site differences in the amount of precipitation, browsing history, soil type, and leeching likely exist. Site effects have been detected in other studies of plant response to clipping/ browsing, but have been suggested by other authors to be less important and more flexible than the morphological and chemical responses of plants to damage, which tend to be of a more generalized nature across the landscape (Danell et al. 1997).

At the beginning of the study, we applied specific clipping treatments $(0 \%, 33 \%, 66 \%$, and $100 \%)$ to trees in midwinter. Because of the absence of exclosures, however, moose browsed the experimental trees after our clipping. Further, burial of lower branches by snow resulted in an under-clipping of lower branches. Consequently, total shoot removal (clipping and browsing) had to be reassessed in the spring and subsequently treated as a covariate rather than as distinct treatment levels in our analyses. The complexity of the design makes it difficult to interpret specific site effects. The inability to exclude natural browsing from our study meant that the level of the covariate could change from year to year. This change meant that we only assessed one year of data from the 2- and 4-year sites without following within-site effects for longer periods of time. Our results, therefore, should be treated as a possible indication of a longer-term response that needs further study.

\section{IMPLICATIONS}

Regardless of any site effect detected, Scouler's willow appears to compensate for brush cutting by producing large compensatory shoots, low in digestibility in the long term and lower in tannin content in the short term relative to shoots of uncut willows. Although the measured responses of Scouler's willow shoots for 2 and 4 years after brush cutting suggest an initial response of willow to brush cutting and clipping, our data cannot portray the full range of morphological and chemical changes that likely occur throughout the succession of the shrub field. We also do not know how moose responded behaviorally to these changes in willow chemistry and morphology. Although the study area is extensively used by moose (e.g., the confounding of our clipping experiment discussed above), we do not know how the habitat use and selection of shoots by moose change after brush cutting operations. The relative importance of changes in available biomass and shoot chemistry could be either amplified or minimized, depending on how moose respond spatially to these management activities.

Brush cutting likely will continue to replace herbicide treatment of broad-leaved plants in many jurisdictions. As such, understanding the influence of brush cutting on plant response and quality in both the short and long term is integral to understanding the influence of this form of vegetation management on range quality. To better understand the effects of brush cutting, we recommend that long-term studies, ideally that make use of exclosures to better control for clipping and browsing effects, be undertaken. Given the unexpected 
importance of site in our study, we further recommend that such work should maximize the number of sites examined so that stronger inference can be made to the effects of brush cutting on browse for moose and other ungulates.

\section{ACKNOWLEDGMENTS}

The authors wish to thank M. Deli, C. Smith, H. Cedervind, V. Corbett, S. Gibson, B. Clayton, J. Wiersma, and R. Brown for research assistance. The helpful comments of K. Parker and D. Heard on a draft of this manuscript are appreciated.

\section{LITERATURE CITED}

Aarssen, L. W., AND D. L. IRWIN. 1991. What selection: herbivory or competition? Oikos 60:261-262.

Alldredge, M. W., J. M. Peek, and W. A. Wall. 2002. Nutritional quality of forages used by elk in northern Idaho. Journal of Range Management 55:253-259.

Allegretti, L. I., C. B. Passera, and A. B. Robles. 1997. Short- and long-term effects of shrub management on vegetation in the Monte, Argentina. Journal of Arid Environments 35:685-693.

Bell, F. W., R. A. Lautenschlager, R. G. Wagner, D. G. Pitt, J. W. Hawkins, and K. R. RIDE. 1997. Motor-manual, mechanical, and herbicide release affect early successional vegetation in northwestern Ontario. Forestry Chronicle 73:61-68.

Bergström, R. K., and K. Danell. 1987. Effects of simulated winter browsing by moose on morphology and biomass of two birch species. Journal of Ecology 75:533-544.

Bergström, R., and C. Guillet. 2002. Summer browsing by large herbivores in short-rotation willow plantations. Biomass and Bioenergy 23:27-32.

Blair, R. M., H. L. Short, L. F. Burkhart, A. Harrell, and J. B. Whelan. 1980. Seasonality of nutrient quality and digestibility of three southern deer browse species. Research Paper S0-161. New Orleans, LA: US Department of Agriculture, Forest Service, Southern Forest Experiment Station. 13 p.

Bryant, J. P., F. S. Chapin, and D. R. Klein. 1983. Carbon nutrient balance of boreal plants in relation to vertebrate herbivory. Oikos 40:357-368.

Bryant, J. P., G. D. Wieland, T. Clausen, and P. Kuropat. 1985. Interactions of snowshoe hares and feltleaf willow in Alaska. Ecology 66:1564-1573.

Coley, P. D., J. P. Bryant, and F. S. Chapin III. 1985. Resource availability and plant antiherbivore defense. Science 230:895-899.

Danell, K., and R. Bergström. 1985. Studies on interactions between moose and two species of birch in Sweden: a review. In: F. D. Provenza, J. T. Flinders, and E. D. McArthur [EDS.]. Proceedings of a Symposium on Plant-Herbivore Interactions; 7-9 August 1985; Snowbird, UT. Ogden, UT: US Department of Agriculture, Forest Service Intermountain Research Station Publication INT222. p. $48-57$.

Danell, K., and R. Bergström. 1989. Winter browsing by moose on two birch species: impact on food resources. Oikos 54:11-18.

Danell, K., T. Elmovist, L. Ericson, and A. Salomonson. 1987. Are there general patterns in bark-eating by voles on different shoot types from woody plants? Oikos 50:396-402.

Danell, K., E. Haukioja, and K. Huss-Danell. 1997. Morphological and chemical responses of mountain birch leaves and shoots to winter browsing along a gradient of plant productivity. Ecoscience 4:296-303.

Danell, K., K. Huss-Danell, and R. Bergström. 1985. Interactions between browsing moose and two species of birch in Sweden. Ecology 66:1867-1878.

Goering, H. K., and P. J. Van Soest. 1970. Forage fiber analyses (apparatus, reagents, procedures, and some applications). Washington, DC: US Department of Agriculture, Agricultural Research Service, US Government Printing Office. Agriculture Handbook 379:1-20.
Gross, J. E., L. A. Shipley, N. T. Hobbs, D. E. Spalinger, and B. A. Wunder. 1993. Functional response of herbivores in food-concentrated patches: tests of a mechanistic model. Ecology 74:778-791.

Hagerman, A. E. 1987. Radial diffusion method for determining tannin in plant extracts. Journal of Chemical Ecology 13:437-449.

Hagerman, A. E., AND C. T. RobBins. 1993. Specificity of tannin-binding salivary proteins relative to diet selection by mammals. Canadian Journal of Zoology 71:628-633.

Hanley, T. A., C. T. Robbins, A. E. Hagerman, and C. McArthur. 1992. Predicting digestible protein and digestible dry matter in tannin-containing forages consumed by ruminants. Ecology 73:537-541.

HarRington, C. A. 1984. Factors influencing initial sprouting of red alder. Canadian Journal of Forest Research 14:357-361.

Hellinga, D., O. Oftedal, and B. Henen. 1998. Nitrogen analysis: comparison of carbon-hydrogen-nitrogen (CHN) gas analysis to Kjeldahl procedures. Proceedings of the Comparative Nutrition Society 2:79-82.

Hessl, A. E., and L. J. Graumlich. 2002. Interactive effects of human activities, herbivory and fire on quaking aspen (Populus tremuloides) age structures in western Wyoming. Journal of Biogeography 29:889-902.

HJELJoRd, 0. 1994. Moose (Alces alces) and mountain hare (Lepus timidus) use of conifer plantations following glyphosate application. Norwegian Journal of Agricultural Sciences 8:181-188.

HJelJoRd, O., AND S. Grønvold. 1988. Glyphosate application in forest-ecological aspects VI. Browsing by moose (Alces alces) in relation to chemical and mechanical brush control. Scandinavian Journal of Forest Research 3:115-121.

JuntheIKKI, M.-R. 1996. Comparison of tannin-binding proteins in saliva of Scandinavian and north American moose (Alces alces). Biochemical Systematics and Ecology 24:595-601.

LaUtensCHLAGER, R. A. 1993. Response of wildlife to forest herbicide applications in northern coniferous ecosystems. Canadian Journal of Forest Research 23:2286-2299.

Milliken, G. A., And D. E. Johnson. 1984. Analysis of messy data. Volume I. Designed experiments. New York, NY: Van Nostrand Reinhold. 473 p.

Nellemann, C. 1990. Vegetation management to improve moose browse in interior Alaska [thesis]. Ås, Norway: Agricultural University of Norway. $48 \mathrm{p}$.

Palo, R. T. 1984. Distribution of birch (Betula spp.), willow (Salix spp.) and poplar (Populus spp.) secondary metabolites and their potential role as chemical defense against herbivores. Journal of Chemical Ecology 10:499-520.

Pella, E., and B. Colombo. 1973. Study of carbon, hydrogen and nitrogen determination by combustion gas chromatography. Mikrochimica Acta 5:697-719.

Posner, S. D., and P. A. Jordan. 2002. Competitive effects on plantation white spruce saplings from shrubs that are important browse for moose. Forest Science 48:283-289.

Raymond, K. S., F. A. Servello, B. Griffith, and W. E. Eschrolz. 1996. Winter foraging ecology of moose on glyphosate-treated clearcuts in Maine. Journal of Wildlife Management 60:753-763.

REA, R. V. 1999. Response of Scouler's willow (Salix scouleriana) to mechanical brushing: implications to the quality of winter browse for moose (Alces alces) [thesis]. Prince George, British Columbia, Canada: University of Northern British Columbia. $103 \mathrm{p}$.

Rea, R. V., and M. P. Gillingham. 2001. The impact of the timing of brush management on the nutritional value of woody browse for moose Alces alces. Journal of Applied Ecology 38:710-719.

RisenHoOver, K. L. 1987. Intraspecific variation in moose preference for willows. In: F. D. Provenza, J. T. Flinders, and E. D. McArthur [eds.]. Proceedings of a Symposium on Plant-Herbivore Interactions; 7-9 August 1985; Snowbird, UT. Ogden, UT: US Department of Agriculture, Forest Service Intermountain Research Station Publication INT-222. p. 58-63.

Santillo, D. J. 1994. Observations on moose, Alces alces, habitat and use on herbicide-treated clearcuts in Maine. Canadian Field Naturalist 108:22-25.

SAS. 2005. Statistical Analysis Systems, version 9.1. Cary, NC: SAS Institute, Inc. 
Schindler, J. R., T. E. Fulbright, and T. D. A. Forbes. 2004. Long-term effects of roller chopping on antiherbivore defences in three shrub species. Journal of Arid Environments 56:181-192.

Sennerby-ForsSE, L., AND L. ZsufFa. 1995. Bud structure and resprouting in coppiced stools of Salix viminalis L., S. eriocephala Michx. and Salix amygdaloides Anders. Trees 9:224-234.

Shipley, L. A., J. E. Gross, D. E. Spalinger, N. T. Hobbs, and B. A. Wunder. 1994. The scaling of intake rate in mammalian herbivores. American Naturalist 143:1055-1082.

Shipley, L. A., and D. E. Spalinger. 1992. Mechanics of browsing in dense food patches: effects of plant and animal morphology on intake rate. Canadian Journal of Zoology 70:1743-1752.
Singer, F. J., L. C. Lauryl, and R. C. Cates. 1994. Ungulate herbivory of willow on Yellowstone's northern winter range. Journal of Range Management 47:435-443.

Spalinger, D. E., C. T. Robbins, and T. A. Hanley. 1986. The assessment of handling time in ruminants: the effect of plant chemical and physical structure on the rate of breakdown of plant particles in the rumen of mule deer and elk. Canadian Journal of Zoology 64:312-321.

Tabachnick, B. G., and L. S. Fidell. 1996. Using multivariate statistics. 3rd ed. New York, NY: HarperCollins College Publishers. 880 p.

ZaR, J. H. 1999. Biostatistical analysis. 4th ed. Upper Saddle River, NJ: Prentice Hall. $718 p$. 